\title{
Study on the Practical Teaching System of Human Resource Management in Applied Undergraduate
}

\author{
Ning Cui* \\ College of Humanities \\ Tianjin Agricultural University \\ Tianjin, China
}

\author{
Wei Zhang \\ College of Humanities \\ Tianjin Agricultural University \\ Tianjin, China
}

\begin{abstract}
With the development of times, practical ability is becoming more and more crucial to decide whether students are competent in labor market. Human resource management is very practical, students majored in HRM are required to have high practical ability. Practical ability and innovation ability are two key points to decide whether students are qualified to be an HR. Presently, many problems exists in practical teaching system of human resource management in universities, the problems include: the setting of practical teaching system is irrational; implementation of practical teaching is extremely difficult; teachers are incapable in implementing practical teaching; the laboratory construction is not complete. For human resource management in applied undergraduate to raise students' practical ability and innovation ability are problems demanding prompt solution, and it is also meaningful for education reform and development of practical teaching. The thesis through discussion on status of practical teaching of human resource management in applied undergraduate concluded that construction of practical teaching system of human resource management in applied undergraduate depends on the setting, support, implementation and feedback of the practical teaching system.
\end{abstract}

Keywords-Applied Undergraduate; Human resource management; Practical Teaching System

\section{STATUS ANALYSIS ON PRACTICAL TEACHING OF HRM IN APPLIED UNDERGRADUATE}

\section{A. The Setting of Practical Teaching System Is Irrational}

Universities of China, influenced by traditional idea of emphasizing more on theory teaching, still take practical teaching as supplement [1]. The talent-raising mode of value theory more than practice, and value knowledge teaching more than ability raising lead to a unsatisfactory outcome of practical teaching. For one thing, in some universities, when the HRM major is founded, only theory teaching is included in the curriculum plan, without any class hours allocated for corresponding practical teaching, the content and time arrangement are also not sufficient enough to achieve the goal of 'cultivating students' application ability in the field of HRM". For another thing, some universities only muddle through their work, leave practical teaching a mere formality. Students are merely showed to pay a in-house visit on nearby enterprises for one or two days. Practical teaching arrangement like this is not sufficient for students to take part in daily operation of enterprises to get a deeper understanding on content and process of HRM, that is to say the theory learned from class will be left untested.

\section{B. Implementation of Practical Teaching Is Extremely Difficult}

For universities, practical teaching of HRM should involve multiple links, however, presently the common practical of universities in China is to ask students to find a place and do the field work all by themselves. Hence, quality of teaching cannot be guaranteed under this decentralized practical teaching mode. For enterprises, every organization has its own separated management system, the intrusion of students work as interns will disrupt the management regularity. Additionally, HRM function of enterprises always involves many trade secret, for self-protection purpose the enterprises will not allow students to be involved in their substantive operation, and thus, they are unwilling to accept interns in HR department.

\section{Teachers Are Incapable in Implementing Practical Teaching}

Specialized courses of HRM are required to be highly practical, and hence, teachers are required to be capable both in theory and in actual operation. However, many of university teachers become a teacher right after their graduation, they are proficient in theory but deficient in actual operation [2]. They are incapable in directing students in practice, and the outcome can be imagined. Besides, it is difficulty to found a sound and orderly training system to improve teachers' practical ability due to lack of educational expenditure and irrational curriculum arrangement. That greatly hinders the achievement on objectives of cultivating and improving students' practical ability.

\section{The Laboratory Construction Is Not Complete}

Specialized laboratory should be a crucial link in practical teaching within campus. It is a medium for students to integrate theory with practice, and very effective in improving students' competency quality and practical ability. However, the investment in laboratory is desperately inadequate. Even some universities have already established some specialized labs, the labs have been equipped with hardware facilities, they are always short of expenditure allocated for software facilities. For example, some of HR labs, such as Talent Quality 
Assessment Lab, are not functional for having not been equipped with proper software and thus they, and thus the impedes qualification improvement of talent.

\section{CONSTRUCTION OF PRACTICAL TEACHING SYSTEM OF HRM IN APPLIED UNDER GRADUATE}

\section{A. Setting of the Practical Teaching System}

\section{1) Specified the scope of practical teaching system}

The implementation of HRM practical teaching comes in many forms, all forms should be integrated in order to achieve the desired effect of cultivating talent [3]. We think the practical teaching system based on competency consist of two modules, one is in-campus practice, the other is off-campus practice, they complement each other. In-campus practical includes curriculum practical (ex. case analysis, curriculum design, etc.), HRM software operation and graduation thesis. Off-campus practical include holiday social practice, specialty practice, graduation field work, etc.

\section{2) Increase teaching hours allocated for practical} teaching

There is a big gap between curriculum provided in HRM by universities in China and universities in developed countries. For instance, the ratio of practical teaching to theory teaching in American universities is 3:1, in Britain is 2:1, and in German universities, the experiments, designs and practices included in curriculum plan takes $2 / 3$ of it total class hours. We should learn from the experiences of developed countries, to decrease hours allocated for theory teaching, and correspondingly increase the hours for practical teaching, to facilitate students to understand specialized courses better. Considering the condition of Chinese universities, best effort should be made to improve the ratio of practical teaching to theory teaching to reach 1:4.

\section{B. Support System of Practical Teaching}

\section{1) Strengthen the bipolar teacher team building}

Team-building for teachers is important to guarantee the teaching quality [4]. For one thing, multiple channels should be developed to improve teachers' practical ability. To achieve this, firstly, opportunities should be provided for teachers to get further education, such as to provide paid opportunity for teachers to study aboard or other provinces of China; secondly, teachers should be arranged to take a temporary position to gather more field experience; thirdly, teachers should be encouraged to be actively involved in horizontal project collaborated with business. For another thing, external assistance should be introduced. Firstly, professors from wellknown universities and with high practical ability and high theoretical level should be invited as part-time professor; secondly, HR specialists with profound practical experiences should be employed to work as coaches to guide practical activities for students.

\section{2) Construction of the simulation laboratory for Human} Resource Management

Construction of modernized and specialized laboratory for HRM facilitates students to get a systematic and all-arounded understanding on all HRM activities, and to raise students' ability to analyze and solve practical problem through simulation training such as, personnel assessment experiment, simulation job fair, simulated labor arbitration, and management role play. The labs should not only be equipped with necessary HRM software and experiment guidebook, but also a real and complete set of operational material related to every link of HRM such as: HRM work plan, job specification, labor contract, employee handbook, recruitment plan, reward management system, employee assessment and testing plan, employee training plan, etc.

\section{3) Develop the practical teaching base}

Lack of practical teaching base has always been a impediment for the development of HRM practical teaching. The solution based on whether a mutually beneficial win-win mode can be established. To achieve this, firstly, universities should cooperate with enterprises to raise and supply talents tailored to specific need of enterprises; secondly, teachers should serve as consultant to solve practical problems met by enterprises, in return, enterprises should serve as bases for practical teaching; thirdly, universities can choose to establish their own tertiary industries [5]. Tertiary industries can serve as bases and a medium for teachers to get more field experiences.

\section{Implementation of Practical Teaching System}

Practical teaching system should be carried out step by step. The total arrangement should follow proper orders, that is from theory to practical and then back to theory.

First of all, practical should begin form the second semester, the whole content should extend beyond social survey in summer vacation to include internship lasting for 1-2 weeks from the beginning of the next semester. Students will be made to understand basic content of each HRM activities, and experienced HR specialists should be invited to make instruction. The field work experience will facilitate students to directly understand basic information of HRM before been given the specialized courses in HRM. It is also conductive to raise students' interest and further facilitate them to get better and precise understanding on key and difficult content. Secondly, during learning different practical teaching topic should be arranged in accordance with corresponding specialized courses. (see TABLE I)

TABLE I. CONTENT OF HRM SPECIALIZED COURSES PRACTICAL TEACHING

\begin{tabular}{|c|c|}
\hline Course Name & Course Name \\
\hline $\begin{array}{c}\text { Human Resource } \\
\text { Planning }\end{array}$ & To develop HRP plan and HRM system \\
\hline $\begin{array}{c}\text { Recruitment, Screening } \\
\text { and Hiring }\end{array}$ & $\begin{array}{c}\text { To develop recruitment plan and interview } \\
\text { skills }\end{array}$ \\
\hline $\begin{array}{c}\text { Employee Training and } \\
\text { Development }\end{array}$ & $\begin{array}{c}\text { To develop training plan and to design } \\
\text { implementation plan }\end{array}$ \\
\hline $\begin{array}{c}\text { Performance } \\
\text { Management }\end{array}$ & $\begin{array}{c}\text { To develop performance management } \\
\text { plan, to conduct performance } \\
\text { communication }\end{array}$ \\
\hline $\begin{array}{c}\text { Compensation } \\
\text { Management }\end{array}$ & $\begin{array}{c}\text { To develop compensation plan and } \\
\text { incentive plan }\end{array}$ \\
\hline $\begin{array}{c}\text { Labor-relation } \\
\text { Management }\end{array}$ & $\begin{array}{c}\text { To develop labor contract management } \\
\text { system and employee satisfaction survey } \\
\text { plan }\end{array}$ \\
\hline $\begin{array}{c}\text { Career Planning and } \\
\text { Management }\end{array}$ & $\begin{array}{c}\text { To develop career plan and organizational } \\
\text { career planning system }\end{array}$ \\
\hline
\end{tabular}


Thirdly, when all specialized courses are learned, students should be sent to work as interns to practical what they learn comprehensively in order to enhance their understanding of specialized knowledge. Lastly, to send senior students with HR knowledge and skills to conduct graduation field work will facilitate their graduation thesis writing.

\section{Feedback of the Practical Teaching System}

To raise students' competency, the feedback for implementation of practical teaching system should come in two forms. One is to invite HR specialists from enterprises to hold a symposium for students after graduation field work, and to discuss specific problems met by students during practice. Although every students have a coach, there are still difficulties left unsolved for lack of experiences and practical abilities. The other is to connect graduation thesis with practical teaching. Presently, problems still exist in topic selection of graduation thesis, such as: too random, too formalized, and too less connection with the content of practical teaching. Besides, the whole writing process is more like to put all sorts of materials together. Thus the content of the thesis is disconnected with practice, that hinders further implementation of practical teaching [5]. To solve the problem, students should be required to select the topic of their thesis in connection with their graduation field work. Hence, firstly theory and practical can be integrated to make students understand what they learn better, and to make the writing of graduation thesis more meaningful; secondly, through writing, students can conduct a integral conclusion of practical teaching activities throughout their college life, and become fully prepared for what they will face after graduation.

\section{CONCLUSION}

In conclusion, according to the current problems that major in practical teaching of Human Resource Management in applied undergraduate, the article construct the practical teaching system of HRM which including setting, Support, implementation and feedback. The practical system provides guidance for sustainable development for the Human Resource Management in applied undergraduate.

\section{REFERENCES}

[1] Sun Rongxia. Research on the Practical Teaching System of Human Resource Management Based on Competency Model [J]. China Adult Education,2013(19):188-191.(In Chinese).

[2] Pan Taiping. Reflections on Improving the Practical Ability of Human Resource Management Specialty in Applied University [J]. Value Engineering, 2018(07):250-252. (In Chinese).

[3] John Bratton, Jeff Gold. Human Resource Management, 5th Edition: Theory and Practice [M]. New York: Palgrave Macmillan, 2012.

[4] Xin Zhu. Research on the Construction of Practical Teaching System of Human Resource Management in Applied Undergraduate [J]. Journal of Wuzhou University, 2017 (02):84-87. (In Chinese).

[5] Xia Zhang. Reform and Practice of Practical Teaching System of Human Resource Management [J]. Shihezi Science and Technology, 2017(04):39-41. (In Chinese).

[6] Michael Armstrong, Stephen Taylor. Armstrong's Handbook of Human Resource Management Practice [M]. London: Kogan Page, 2017. 